Original Research Article

\title{
Safety and efficacy of tirapazamine as anti-cancer drug: a meta-analysis of randomized controlled trials
}

\author{
Sharanabasayyaswamy B. Hiremath ${ }^{1 *}$, Srinivas Lokikere Devendrappa ${ }^{2}$
}

${ }^{1}$ Department of Pharmacology, Kodagu Institute of Medical Sciences, Madikeri, Karnataka, India

${ }^{2}$ Department of Pharmacology, JJM Medical College,

Davangere, Karnataka, India

Received: 09 February 2018

Accepted: 12 March 2018

\section{*Correspondence to:}

Dr. Sharanabasayyaswamy B.

Hiremath,

Email:dr.sharan83@yahoo.com

Copyright: (C) the author(s), publisher and licensee Medip Academy. This is an openaccess article distributed under the terms of the Creative Commons Attribution NonCommercial License, which permits unrestricted noncommercial use, distribution, and reproduction in any medium, provided the original work is properly cited.

\begin{abstract}
Background: The benefits of achieving better response by adding tirapazamine, a specific hypoxic cancer cell killer to chemo and or radiotherapy is contradictory. This study aims at analyzing the efficacy and safety of tirapazamine, apart from understanding the reasons for its doubtful and inconsistent benefits.

Methods: Electronic database search in PUBMED, EMBASE, Cochrane library was conducted using search term "tirapazamine". Randomized or cross-over studies comparing effects of tirapazamine vs other active treatment or placebo in patients $>18$ yrs with any type of cancers were included under analysis. Overall Survival rate was the primary outcome measure while the incidences of grade- 3 and 4 adverse drug reactions were the secondary outcome measure. Inverse variance method and both random and fixed effect models were used in the analysis by RevMan 5.3 software.

Results: Total six studies were eligible with 1034 patients included in the analysis. Tirapazamine failed to show significant effect on overall survival rate at the end of one year (HR: 0.96, 95\% CI: 0.88, 1.05), two year (HR: 1.04, 95\% CI: $0.98,1.12)$, three year (HR: $1.01,95 \%$ CI: $0.89,1.15)$ and five year (HR: 0.97 , 95\% CI: $0.77,1.23$ ) compared to placebo group. There was a significantly higher incidence of muscle cramps (Risk Difference, RD: 0.06, 95\% CI: 0.02, 0.11) and dermal adverse events (RD: 0.03, 95\% CI: 0.01, 0.06) in tirapazamine group. Conclusions: With the available evidences from clinical trials and preclinical studies, use of tirapazamine may not be justifiable and so is to side line this drug as another failed drug.
\end{abstract}

Keywords: Cancer, Overall survival, Tirapazamine

\section{INTRODUCTION}

Cancer is the leading cause of death worldwide both in developing and developed countries alike. ${ }^{1}$ In Indian scenario the incidence of cancer was supposed to increase from 0.8 million in 2001 to 1.2 million by $2016 .^{2}$ Cancer of lung, esophagus and stomach form the major proportion of cancers in men while the cervical, breast and oral cancers predominate females. ${ }^{2}$ The major feature of the solid cancer tumors is the presence of poorly oxygenated areas leading to development of hypoxic cells or quiescent cells which are prone for development of radiotherapy and chemotherapy resistant cancer cells. ${ }^{3}$ Presence of hypoxia and hypoxic cells is a stimulus for angiogenesis and predisposes to metastasis. ${ }^{3}$ The concept of killing these hypoxic cancer cells which once was considered as a problem has been considered as opportunity and lead to development of drugs that selectively targeted hypoxic cancer cells. ${ }^{4}$ One such drug, tirazapamine gained attention and interest owing to its chemo and radio sensitizing effects. ${ }^{5}$ It acts by inducing irreversible DNA doublestrand break and found to be synergistic especially with platinum based cancer chemotherapeutic agent cisplatinum. ${ }^{5}$ Drug showed positive results from preclinical study models and was found to have mixed benefits in few of the phase- 2 and 3 clinical trials. ${ }^{5-11}$ Whether this drug is a complete failure is yet to be 
confirmed before sidelining it as a failed drug. Hence this study aims at analyzing the efficacy and safety of tirapazamine apart from understanding reasons and the possible solutions for its inconsistent benefits.

\section{METHODS}

\section{Eligibity criteria}

Either cross-over or randomized trials with head-to-head comparison of tirapazamine with placebo or any active comparator drug in patients aged $>18$ yrs with any type of cancers were eligible for inclusion. There was no restriction applied on the basis of number of sample size used in the studies. However, those studies with incomplete data required for statistical analysis or those published as abstracts were considered for exclusion. We contacted the corresponding authors to access missing or other required data whenever necessary.

\section{Literature search methodology}

Two authors independently conducted electronic database search in PUBMED, Cochrane library and EMBASE for the randomized trials or cross-over trials using search terms "Tirapazamine". Limits applied for the search in PUBMED were "randomized controlled studies", and "humans" while the limits applied for search in EMBASE were "randomized controlled trial" "conference paper" "article" "article in press" "embase" and "humans". No limits were applied in Cochrane library search. No language restriction was applied. Search was limited to studies published up to 30th June 2016 and study period was extending from July 2016 to August 2016. Additional manual search of some of the relevant review articles was also conducted to search for any missed studies.

\section{Data extraction and synthesis}

Two authors were involved in independent extraction of all required data in a pre-designed standard data extraction form. Differences between the authors on to the data extracted were resolved after achieving consensus between the authors and then the final data sheet was prepared. Screening for the eligible studies was conducted by going through the titles and abstracts of all studies retrieved from literature search methodology. This was followed by screening of the full text of potential articles to screen for availability of required data and other parameters to assess their eligibility for inclusion. Data extracted from studies meeting eligibility criteria included baseline demographic, clinical data and other data required for estimation of outcome measures. The method followed to extract the overall survival rates at different time intervals was based on the Kaplan-Meier curve available from the included studies. The procedure and software used in extraction of this data was as described in an article. ${ }^{12}$ Efficacy parameters extracted were overall survival (OS) rate and safety parameters extracted were number and type of delayed treatment-related adverse drug reactions (ADRs).
Authors did not seek for the unpublished data or the data from the unpublished studies.

\section{Outcome measures}

Primary outcome measure was OS rate in terms of percentage of patients alive at different time periods ranging from one year to five year. OS rate defined as the percentage of patients alive for a certain period of time after they were started with treatment, irrespective of complete or partial response and recurrence of the disease. Secondary outcome measures were number and type of delayed treatment-related ADRs.

\section{Quality evaluation and publication bias assessment}

Un-blinded quality assessment of published data of eligible studies was independently done by two authors as described in an article. ${ }^{13}$ In addition, the risk of bias assessment was also done using Cochrane Collaboration's tool. ${ }^{14}$ Discrepancies in allotting the quality assessment scores and level of bias in the individual studies were sorted after arriving at consensus between the authors. Funnel plot method was used for assessment of publication bias.

\section{Statistical methods}

OS rate between two groups were assessed by calculating the Risk Ratio (RR) and Hazard Ratio (HR). Number and type of ADRs were estimated by calculating Risk Difference (RD). Mantel-Haenszel method and both fixed and random effect models were used in analysis of RR and RD. HR was estimated by calculating Observed-Expected (O-E) values and variance $(\mathrm{V})$ values of each study at different time intervals using the formulas as described in an article. ${ }^{12}$ These values were then used in HR analysis by Exp $((\mathrm{O}-\mathrm{E}) / \mathrm{V})$ method and fixed effect model. Subgroup analysis based on the type of cancer and type intervention was done to test the sensitivity and bias of the results. Sensitivity of the results was also analyzed by comparing results of fixed effect model and random effects model. Heterogeneity between the studies was analyzed by using Cochrane $\mathrm{Q}$ test for heterogeneity and $\mathrm{I}^{2}$ test. A chi square test with $\mathrm{P}$ value $<0.10$ and $\mathrm{I}^{2}$ test value of $>50 \%$ was considered as indicator of significant heterogeneity. Statistical analysis was conducted by using RevMan software version 5.3.

\section{RESULTS}

\section{Literature search results}

Figure 1 shows the results of data search and the attrition diagram with number of studies excluded and reasons for exclusion. Excluded studies did not involve those articles published in language other than English. Six RCTs comparing tirapazamine with placebo or other active treatment were eligible and included in the analysis. None 
of the studies were excluded for the incomplete data and for publishing in language other than English.

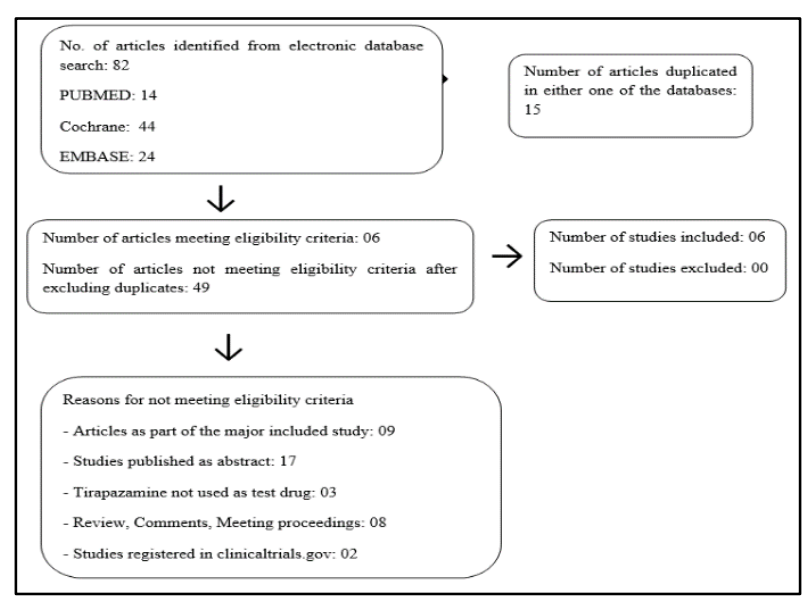

Figure 1: Literature search results and study attrition.

\section{Characters of included studies}

Tables 1 to 4 show the baseline demographic, clinical features and characteristics of individual studies included in the analysis. Studies varied with regard to the types of cancer, wherein three studies were on patients with head and neck cancer, two on lung cancer and one study was on patients with cervical cancer. There were few difference betweeen the studies with regard to treatment regimens used and it will be not possible to mention the details of all the regimens.

In brief, cisplatin at varying doses and frequencies was the common platinum based chemotherapic agent used in all excpet one study where carboplatin was used. Studies varied with regard to use of other chemotherapeutic agent.

Radiotherapy was used in all the three Head and Neck cancer studies at dose of $70 G y$ but at different fractions and time period. Dose and fractions of radiotherapy used in cervical cancer study was quite different from these studies. Tirapazamine was administered in all studies at varying frequencies but prior to radiotherapy and or chemotherapy. Dose of tirapazamine used in Head and Neck cancer studies was $290-300 \mathrm{mg} / \mathrm{m}^{2}$ as single weekly initial induction dose and followed by $160 \mathrm{mg} / \mathrm{m}^{2}$ thrice a week after initiation of simultaneous chemoradiotherapy. High dose of tirapazamine was used in two NSCLC studies ranging from $330-390 \mathrm{mg} / \mathrm{m}^{2}$ once in three weeks. Though low dose $\left(220 \mathrm{mg} / \mathrm{m}^{2}\right)$ of tirapazamine was used in cervical cancer study, it was administered thrice a week.

Table 1: Baseline demographic and clinical features of patients.

\begin{tabular}{|c|c|c|c|c|c|c|}
\hline Factors & \multicolumn{2}{|c|}{$\begin{array}{l}\text { Le et al, } \\
\text { Control TPZ }\end{array}$} & \multicolumn{2}{|c|}{$\begin{array}{l}\text { Rischin et al, } \\
\text { Control TPZ }\end{array}$} & \multicolumn{2}{|c|}{$\begin{array}{l}\text { Rischin et al, } \\
\text { Control TPZ }\end{array}$} \\
\hline Sample size & 29 & 33 & 58 & 63 & 428 & 425 \\
\hline Type of cancer & $\mathrm{H}$ and $\mathrm{N}$ & $\mathrm{H}$ and $\mathrm{N}$ & $\mathrm{H}$ and $\mathrm{N}$ & $\mathrm{H}$ and $\mathrm{N}$ & $\mathrm{H}$ and $\mathrm{N}$ & $\mathrm{H}$ and $\mathrm{N}$ \\
\hline $\begin{array}{l}\text { Age in years } \\
\text { (Range) }\end{array}$ & $59(47-81)$ & $56(39-75)$ & $55(43-75)$ & $58(38-74)$ & $56(23-80)$ & $57(23-77)$ \\
\hline M:F ratio & $27: 2$ & $27: 6$ & $91: 9$ & $79: 21$ & $378: 50$ & $365: 58$ \\
\hline \multicolumn{7}{|c|}{ Primary tumor site } \\
\hline Oropharynx & 17 & 22 & 39 & 46 & 228 & 237 \\
\hline Oral cavity & 01 & 03 & 04 & 02 & 53 & 56 \\
\hline Larynx & 04 & 02 & 05 & 06 & 77 & 71 \\
\hline Hypopharynx & 06 & 05 & 10 & 09 & 70 & 61 \\
\hline Others & 02 & 01 & 00 & 00 & 00 & 00 \\
\hline \multicolumn{7}{|l|}{ Stage of cancer } \\
\hline III & 00 & 00 & 21 & 17 & 60 & 53 \\
\hline IV & 29 & 33 & 79 & 83 & 368 & 372 \\
\hline \multicolumn{7}{|l|}{ Tumor stage } \\
\hline T0 & 01 & 01 & 00 & 00 & 00 & 00 \\
\hline $\mathrm{T} 1$ & 01 & 07 & 03 & 06 & 13 & 16 \\
\hline $\mathrm{T} 2$ & 06 & 10 & 13 & 13 & 61 & 57 \\
\hline $\mathrm{T} 3$ & 07 & 05 & 21 & 25 & 149 & 159 \\
\hline $\mathrm{T} 4$ & 15 & 10 & 21 & 19 & 205 & 193 \\
\hline \multicolumn{7}{|l|}{ Nodal stage } \\
\hline N0 & 00 & 00 & 11 & 07 & 65 & 60 \\
\hline N1 & 02 & 03 & 09 & 10 & 40 & 53 \\
\hline N2 & 22 & 21 & 31 & 35 & 275 & 264 \\
\hline N3 & 05 & 09 & 07 & 11 & 48 & 48 \\
\hline
\end{tabular}




\section{Outcome measures}

Considering the possibility of inter-trial heterogenity, we present the results of random effects model as representatives of true effects on $\mathrm{RR}$ and $\mathrm{RD}$ or results of fixed effect model if there is no inter-trial heterogeneity. Figures 2-5 show the efficacy of tirapazamine on overall survival rate at different time intervals. Two subgroup analyses, one including head and neck cancer studies and another including studies using both chemo and radiotherapy were done. Quite interestingly there were few evidence of inter-trial heterogeneity between the studies even after subgroup analysis. Thugh the results on RR presented are of random effects model, the results were robust as they did not differ significantly with effect size measures of fixed effect model. However, there was evidence of significant publication bias in all the effect size measures estimated. With regards to safety parameters, there was significantly higher incidence of muscle cramps $(\mathrm{RD}=0.06(0.05,0.08))$ and dermal ADRs $(\mathrm{RD}=0.03$ $(0.02,0.05))$ in tirapazamine treated group even in subgroup analyses. However, there was evidence of significant inter-trial heterogeneity and publication bias but the results appeared to be robust considering no major differences with effect size measure estimated by fixed effect model.

Table 2: Baseline demographic and clinical features of patients.

\begin{tabular}{|lllllll|}
\hline Factors & \multicolumn{2}{l}{$\begin{array}{l}\text { Williamson et al } \\
\text { Control TPZ }\end{array}$} & \multicolumn{2}{l}{$\begin{array}{l}\text { von Pawel et al } \\
\text { Control TPZ }\end{array}$} & \multicolumn{3}{l|}{$\begin{array}{l}\text { Disilvestro et al } \\
\text { Control TPZ }\end{array}$} \\
\hline Sample size & 186 & 181 & 219 & 219 & 194 & 425 \\
\hline $\begin{array}{l}\text { Age in years } \\
\text { (Range) }\end{array}$ & $62.6(\mathrm{NA})$ & $63(\mathrm{NA})$ & $59.5(35-82)$ & $56(23-80)$ & 48 (NA) & 47 (NA) \\
\hline M:F ratio & $117: 69$ & $115: 66$ & $144: 75$ & $149: 70$ & $0: 194$ & $0: 184$ \\
\hline Type of cancer & NSCLC & NSCLC & NSCLC & NSCLC & Ca.Cx & Ca.Cx \\
\hline Stage of cancer & & & & & & 33 \\
\hline IB & 00 & 00 & 00 & 00 & 11 & 32 \\
\hline IIA & 00 & 00 & 00 & 00 & 93 & 82 \\
\hline IIB & 00 & 00 & 01 & 00 & 51 & 52 \\
\hline IIIB & 24 & 30 & 35 & 39 & 06 & 07 \\
\hline IV & 162 & 151 & 183 & 179 & \\
\hline
\end{tabular}

M: F = Male:Female, NSCLC $=$ Non-Small-Cell Lung Cancer, Ca.Cx $=$ Cancer of Cervix, NA= Not Available

Table 3: Characteristics of individual studies.

\begin{tabular}{|c|c|c|c|}
\hline Study features & Le et al & Rischin et al & Rischin et al \\
\hline $\begin{array}{l}\text { Study Design } \\
\text { and Duration }\end{array}$ & $\begin{array}{l}\text { Randomized } \\
\text { Phase II, Open label } \\
\text { Parallel group }\end{array}$ & $\begin{array}{l}\text { Randomized } \\
\text { Phase II, Open label } \\
\text { Parallel group }\end{array}$ & $\begin{array}{l}\text { Randomized } \\
\text { Phase III, Open label } \\
\text { Parallel group }\end{array}$ \\
\hline Centers & Single centre & Multi centre & Multicentre \\
\hline Country & USA & Australia and New Zealand & 16 countries \\
\hline Type of cancer & Stage IV, Head and neck & Stage III and IV, Head and neck & Stage III and IV, Head and neck \\
\hline \multirow{2}{*}{$\begin{array}{l}\text { Groups and } \\
\text { Interventions }\end{array}$} & $\begin{array}{l}\text { Control group } \\
\text { 5-FU, PT, RT }\end{array}$ & $\begin{array}{l}\text { Control group } \\
\text { 5-FU, PT, RT }\end{array}$ & $\begin{array}{l}\text { Control group } \\
\text { PT, RT }\end{array}$ \\
\hline & $\begin{array}{l}\text { TPZ group } \\
5-F U, P T+T P Z, R T\end{array}$ & $\begin{array}{l}\text { TPZ group } \\
\text { TPZ, PT, RT }\end{array}$ & $\begin{array}{l}\text { TPZ group } \\
\text { PT, RT, TPZ }\end{array}$ \\
\hline Follow-up data & 5 Years & 3 Years & 2 Years \\
\hline Quality score & $91 \%$ & $85 \%$ & $85 \%$ \\
\hline \multicolumn{4}{|l|}{ Risk of Bias } \\
\hline RSG & UR & UR & UR \\
\hline $\mathrm{AC}$ & HR & LR & LR \\
\hline BPP & UR & HR & HR \\
\hline $\mathrm{BOA}$ & UR & UR & UR \\
\hline IOD & LR & LR & LR \\
\hline SR & LR & LR & LR \\
\hline
\end{tabular}

RSG: Random Sequence Generation, AC: Allocation Concealment, BPP: Blinding of Participants and Personnel, BOA: Blinding of Outcome Assessment, IOD: Incomplete Outcome Data, SR: Selective Reporting, UR: Unclear Risk, HR: High Risk, LR: Low Risk, N/A: Not Available, PT: Cisplatin, RT: Radiotherapy, TPZ: tirapazamin 
Table 4: Characteristics of individual studies.

\begin{tabular}{|c|c|c|c|}
\hline Study features & Williamson et al & von Pawel et al & Disilvestro et al \\
\hline $\begin{array}{l}\text { Study Design } \\
\text { and Duration }\end{array}$ & $\begin{array}{l}\text { Randomized } \\
\text { Phase III, Open label } \\
\text { Parallel group }\end{array}$ & $\begin{array}{l}\text { Randomized } \\
\text { Phase III, Open label } \\
\text { Parallel group }\end{array}$ & $\begin{array}{l}\text { Randomized } \\
\text { Phase III, Open label } \\
\text { Parallel group }\end{array}$ \\
\hline Centers & Single centre & Multi centre & Multicentre \\
\hline Country & USA & 7 countries & USA, Canada \\
\hline Type of cancer & Stage III and IV NSCLC & $\begin{array}{l}\text { Stage IIIB and IV } \\
\text { NSCLC }\end{array}$ & $\begin{array}{l}\text { Stage IIIB and IVA } \\
\text { Cervical cancer }\end{array}$ \\
\hline \multirow{2}{*}{$\begin{array}{l}\text { Groups and } \\
\text { Interventions }\end{array}$} & $\begin{array}{l}\text { Control group } \\
\text { CT, PcT }\end{array}$ & $\begin{array}{l}\text { Control group } \\
\text { PT }\end{array}$ & $\begin{array}{l}\text { Control group } \\
\text { PT, RT }\end{array}$ \\
\hline & $\begin{array}{l}\text { TPZ group: } \\
\text { CT, PcT, TPZ }\end{array}$ & $\begin{array}{l}\text { TPZ group } \\
\text { TPZ, PT }\end{array}$ & $\begin{array}{l}\text { TPZ group } \\
\text { PT, RT, TPZ }\end{array}$ \\
\hline Follow-up data & 1 Years & 1.5 Years & 5 Years \\
\hline Quality score & $85 \%$ & $79 \%$ & $85 \%$ \\
\hline \multicolumn{4}{|l|}{ Risk of Bias } \\
\hline RSG & UR & UR & LR \\
\hline $\mathrm{AC}$ & UR & UR & UR \\
\hline BPP & UR & UR & UR \\
\hline $\mathrm{BOA}$ & UR & UR & UR \\
\hline IOD & LR & LR & LR \\
\hline SR & LR & LR & LR \\
\hline
\end{tabular}

RSG: Random Sequence Generation, AC: Allocation Concealment, BPP: Blinding of Participants and Personnel, BOA: Blinding of Outcome Assessment, IOD: Incomplete Outcome Data, SR: Selective Reporting, UR: Unclear Risk, HR: High Risk, LR: Low Risk, N/A: Not Available, PT: Cisplatin, CT: Carboplatin, PcT: Paclitaxel, RT: Radiotherapy, TPZ: Tirapazamine

\begin{tabular}{|c|c|c|c|c|c|c|c|c|}
\hline \multirow[b]{2}{*}{ Study or Subgroup } & \multicolumn{2}{|c|}{ Tirazone } & \multicolumn{2}{|c|}{ Control } & \multirow[b]{2}{*}{ Weight } & \multirow{2}{*}{$\begin{array}{c}\text { Risk Ratio } \\
\text { M-H, Random, } 95 \% \mathrm{Cl}\end{array}$} & \multirow{2}{*}{\multicolumn{2}{|c|}{$\begin{array}{c}\text { Risk Ratio } \\
\mathrm{M}-\mathrm{H}, \text { Random, } 95 \% \mathrm{Cl}\end{array}$}} \\
\hline & Events & Total & Events & Total & & & & \\
\hline Disilvestro 2014 & 18 & 185 & 14 & 194 & $6.0 \%$ & $1.35[0.69,2.63]$ & & \\
\hline Le 2006 & 5 & 33 & 2 & 29 & $1.3 \%$ & $2.20[0.46,10.48]$ & & \\
\hline Rischi 2005 & 9 & 63 & 15 & 58 & $5.0 \%$ & $0.55[0.26,1.16]$ & & \\
\hline Rischi 2010 & 95 & 425 & 90 & 428 & $22.1 \%$ & $1.06[0.82,1.37]$ & & - \\
\hline von Pawel 2000 & 143 & 219 & 166 & 219 & $34.1 \%$ & $0.86[0.76,0.97]$ & & \\
\hline Williamson 2005 & 123 & 181 & 115 & 186 & $31.5 \%$ & $1.10[0.95,1.28]$ & & \\
\hline Total $(95 \% \mathrm{Cl})$ & & 1106 & & 1114 & $100.0 \%$ & $0.99[0.83,1.18]$ & & \\
\hline Total events & 393 & & 402 & & & & & \\
\hline $\begin{array}{l}\text { Heterogeneity: } \mathrm{Tau}^{2}= \\
\text { Test for overall effect: }\end{array}$ & $\begin{array}{l}0.02 ; \mathrm{Chi}^{2} \\
\mathrm{z}=0.10(\end{array}$ & $\begin{array}{l}=11.1 \\
P=0.9\end{array}$ & $\begin{array}{l}8, \mathrm{df}=5 \text { ( } \\
\text { 2) }\end{array}$ & $P=0.0$ & 5); $1^{2}=55$ & & $\begin{array}{cc}1 & 1 \\
0.7 & 0.85 \\
\text { Favours Tirazone }\end{array}$ & $\begin{array}{ccc}1 & 1.2 & 1.5 \\
\text { Favours Control }\end{array}$ \\
\hline
\end{tabular}

Figure 2: Forest plot showing one-year survival benefits of tirapazamine.

\begin{tabular}{|c|c|c|c|c|c|c|c|}
\hline \multirow[b]{2}{*}{ Study or Subgroup } & \multicolumn{2}{|c|}{ Tirazone } & \multicolumn{2}{|c|}{ Control } & \multirow[b]{2}{*}{ Weight } & \multirow{2}{*}{$\begin{array}{c}\text { Risk Ratio } \\
\text { M-H, Random, } 95 \% \mathrm{Cl}\end{array}$} & \multirow{2}{*}{$\begin{array}{c}\text { Risk Ratio } \\
\mathrm{M}-\mathrm{H}, \text { Random, } 95 \% \mathrm{Cl}\end{array}$} \\
\hline & Events & Total & Events & Total & & & \\
\hline Disilvestro 2014 & 39 & 185 & 37 & 194 & $8.5 \%$ & $1.11[0.74,1.65]$ & \\
\hline Le 2006 & 9 & 33 & 5 & 29 & $1.6 \%$ & $1.58[0.60,4.18]$ & $\longleftarrow$ \\
\hline Rischi 2005 & 20 & 63 & 27 & 58 & $6.8 \%$ & $0.68[0.43,1.08]$ & \\
\hline Rischi 2010 & 145 & 425 & 148 & 428 & $27.4 \%$ & $0.99[0.82,1.19]$ & \\
\hline Williamson 2005 & 166 & 181 & 160 & 186 & $55.6 \%$ & $1.07[0.99,1.15]$ & \\
\hline Total $(95 \% \mathrm{Cl})$ & & 887 & & 895 & $100.0 \%$ & $1.02[0.90,1.16]$ & \\
\hline Total events & 379 & & 377 & & & & \\
\hline \multicolumn{7}{|c|}{ Heterogeneity: $\mathrm{Tau}^{2}=0.01 ; \mathrm{Chi}^{2}=5.64, \mathrm{df}=4(\mathrm{P}=0.23) ; \mathrm{I}^{2}=29 \%$} & $\begin{array}{cccc} & 1 & 1 & 1 \\
& 1 & 1.85 & 1.2 \\
\text { Favours Tirazone } & \text { Favours Control }\end{array}$ \\
\hline
\end{tabular}

Figure 3: Forest plot showing two-year survival benefits of tirapazamine. 


\begin{tabular}{|c|c|c|c|c|c|c|c|}
\hline Study or Subgroup & $\begin{array}{l}\text { Tirazo } \\
\text { Events }\end{array}$ & $\begin{array}{l}\text { he } \\
\text { Total }\end{array}$ & $\begin{array}{l}\text { Contr } \\
\text { Events }\end{array}$ & $\begin{array}{l}\text { ol } \\
\text { Total }\end{array}$ & Weight & $\begin{array}{c}\text { Risk Ratio } \\
\text { M-H, Random, } 95 \% \mathrm{Cl}\end{array}$ & $\begin{array}{c}\text { Risk Ratio } \\
\mathrm{M}-\mathrm{H}, \text { Random, } 95 \% \mathrm{Cl}\end{array}$ \\
\hline Disilvestro 2014 & 55 & 185 & 58 & 194 & $25.7 \%$ & $0.99[0.73,1.35]$ & \\
\hline Le 2006 & 15 & 33 & 7 & 29 & $6.2 \%$ & $1.88[0.89,3.97]$ & \\
\hline Rischi 2005 & 26 & 63 & 29 & 58 & $18.4 \%$ & $0.83[0.56,1.22]$ & \\
\hline Rischi 2010 & 191 & 425 & 171 & 428 & $49.7 \%$ & $1.12[0.96,1.32]$ & \\
\hline Total $(95 \% \mathrm{Cl})$ & & 706 & & 709 & $100.0 \%$ & $1.06[0.88,1.29]$ & \\
\hline Total events & 287 & & 265 & & & & \\
\hline \multicolumn{7}{|c|}{$\begin{array}{l}\text { Heterogeneity: } \text { Tau }^{2}=0.01 ; \mathrm{Ch}^{2}=4.49, \mathrm{df}=3(P=0.21) ;\left.\right|^{2}=33 \% \\
\text { Test for overall effect: } Z=0.62(P=0.54)\end{array}$} & $\begin{array}{ccccc}0.7 & 0.85 & 1 & 1.2 & 1.5 \\
\text { Favours Tirazone } & \text { Favours Control }\end{array}$ \\
\hline
\end{tabular}

Figure 4: Forest plot showing three-year survival benefits of tirapazamine.

\begin{tabular}{|c|c|c|c|c|c|c|c|}
\hline Study or Subgroup & $\begin{array}{l}\text { Tirazo } \\
\text { Events }\end{array}$ & Total & $\begin{array}{l}\text { Contr } \\
\text { Events }\end{array}$ & $\begin{array}{l}\text { ol } \\
\text { Total }\end{array}$ & Weight & $\begin{array}{c}\text { Risk Ratio } \\
\text { M-H, Random, } 95 \% \mathrm{Cl}\end{array}$ & $\begin{array}{c}\text { Risk Ratio } \\
\text { M-H, Random, } 95 \% \mathrm{Cl}\end{array}$ \\
\hline Disilvestro 2014 & 69 & 185 & 76 & 194 & $69.0 \%$ & $0.95[0.74,1.23]$ & \\
\hline Le 2006 & 17 & 33 & 10 & 29 & $31.0 \%$ & $1.49[0.82,2.72]$ & \\
\hline Total $(95 \% \mathrm{Cl})$ & & 218 & & 223 & $100.0 \%$ & $1.09[0.73,1.65]$ & \\
\hline Total events & 86 & & 86 & & & & \\
\hline \multicolumn{7}{|c|}{$\begin{array}{l}\text { Heterogeneity: } \text { Tau }^{2}=0.05 ; \mathrm{Ch}^{2}=1.83, \mathrm{df}=1(P=0.18) ;\left.\right|^{2}=45 \% \\
\text { Test for overall effect: } Z=0.44(P=0.66)\end{array}$} & $\begin{array}{ccccc}0.5 & 0.7 & 1 & 1.5 & 2 \\
\text { Favours Tirazone } & \text { Favours Control }\end{array}$ \\
\hline
\end{tabular}

Figure 5: Forest plot showing five-year survival benefits of tirapazamine.

\section{DISCUSSION}

Results of our study do not justify the use of tirapazamine as an adjuvant to cancer chemotherapy and or radiotherapy. Significance and long-term implications of higher incidences of muscle cramps as ADRs in patients treated with tirapazamine is unclear. However, before making a concluding remark on the role of tirapazamine, it is essential to understand the reasons for lack of significant effects with tirapazamine in the background complexity of treating the hypoxic cancer cells. Perhaps finding the solutions to these problems may help in designing or selecting better drugs in future. Multiple factors have been found to influence the efficacy of the tirapazamine which may or may not be extrapolated to other bio-reductive or hypoxic-cell specific anticancer drugs. These factors might have played determining role in the efficacy of tirapazamine and perhaps variable responses to it as observed in different studies. Authors believe that among these factors, tumor microenvironment, activation of tirapazamine, diffusion of tirapazamine across the multicellular layer, damage to blood vessels by tirapazamine and ability of the cancer cells to repair DNA damage induced by tirapazamine are the major determinants. Apart from these factors, intracellular $\mathrm{pH}$ of the cancer cells, expression of certain biomarkers and other proteins by cancer cells, timing and method of administration of tirapazamine and type of major cancer chemotherapeutic agent used might play minor roles.

The most important rather than significant factor is the tumor microenvironment which is determined by the proportion of hypoxic cells and the characteristics of vascularity in the cancer tumor mass. ${ }^{15}$ What becomes complicated after treatment with tirapazamine is the damage to blood vessels caused by it and change in vascularity of the tumor. ${ }^{16}$ Damage to blood vessels in fact increases the proportion of chronically hypoxic cells in the areas of the tumor mass which are already receiving limited blood supply. This increases the proportion of chronically hypoxic cells may prove to be beneficial with regard to increase in the number of cells targeted for tirapazamine action. On the contrary, this effect may be a disadvantage since it not only hinders its own entry but also the entry of simultaneously administered major cancer chemotherapeutic agents into hypoxic areas of the tumor mass. ${ }^{17}$ Hence, what next determines the cytotoxic efficacy of chemotherapeutic agents and tirapazamine is their ability to diffuse across extracellular media and through the non-hypoxic multicellular layers. Diminished diffusion across multicellular layer was hypothesized as one of the 
reason for failure of tirapazamine. ${ }^{18,19}$ However, this may not be a major drawback provided longer time intervals are given between the administration of subsequent doses of tirapazamine which might provide time for revascularization of the tumor mass. ${ }^{20}$

Alternatively, inducing hyperthermia can also be exploited as a means to enhance the vascularity to the tumor mass and thus delivery of the drugs. ${ }^{21}$ Use of biodegradable implant, special drug delivery systems and other prospects may also solve the issue of diffusion of tirapazamine. ${ }^{22,23}$ Even when drug manages to attain sufficient quantity of concentration in the hypoxic areas by any of these approaches, activation of tirapazamine into bio-reductive molecule acts as another determinant of its cytotoxic potential. Activation of tirapazamine inside the chronically hypoxic cells occurs by both cytosolic and nuclear p450 reductase enzymes. ${ }^{24}$ It is the expression of sufficient quantity of nuclear reductase enzymes rather than cytosolic reductase enzymes that determines the DNA damaging potential of tirapazamine. ${ }^{24}$

The final and most important factor which perhaps may be the ultimate determinant of the cytotoxicity potential of tirapazamine is the ability of cancer cells to repair DNA damage induced by tirapazamine. ${ }^{25}$ In our view, these two factors could have played major behind lack of significant benefits with tirapazamine in most of the clinical trials. It's difficult unless screened otherwise to determine the cancers with the ability to repair the DNA damage induced by tirapazamine. Under these scenarios, since the platinum based anticancer drugs and tirapazamine have similar mechanism of action, use of anticancer drug with different mechanism of actions could be ideal and synergistic. ${ }^{26,27}$ Selection of this anticancer drug(s) should probably be guided based on the cell culture assay for drug sensitivity.

Of the other factors which may be significant but perhaps not applicable in all conditions or types of cancers are the expression of biomarkers and other proteins. Increased intracellular glutathione (GSH) level and over expression of Bcl-2 were found to be associated with decreased response to tirapazamine. ${ }^{28,29}$ Over expression of NOS (Nitric oxide synthase) and presence of p53 are associated with better response to tirapazamine. ${ }^{30,31}$ These markers and markers of chronic hypoxia like hypoxia-inducible factor-1alpha(HIF-1alpha), carbonic anhydrase 9 (CA 9) and glucose transporter 1 (GLUT1) may help in judging the role of tirapazamine. ${ }^{32}$

Finally, the intracellular $\mathrm{pH}$ is also found to be an independent factor, independent of the oxygenation status of the cells in determining the cytotoxicity of tirapazamine. ${ }^{33}$ Even the hypoxic cancer cells with high pH showed diminished effects and non-hypoxic cells with low $\mathrm{pH}$ showed potentiated effects to tirapazamine. With regard to higher incidences of muscle cramps as ADRs, loss of mitochondrial membrane was hypothesized as the reason for muscle cramps. ${ }^{34}$ We would like to hypothesize that since the skeletal muscles express GLUT1 even under basal conditions, affinity of tirapazamine to cells expressing GLUT1 could also be responsible for higher incidences of muscle cramps. ${ }^{35}$

\section{CONCLUSION}

To conclude, it is unjustifiable to label tirapazamine as a failed drug. Like any other cancer chemotherapeutic agent it may need to be used in selective type of cancer. Assessing the proportion of hypoxic cells in tumor mass by PET scan or by estimation of biomarkers like Carbonic Anhydrase, p16, HIF-1 factor may help in deciding its use as adjuvant. Use of analogues of tirapazamine with better penetrability or other simpler alternative ways to enhance its diffusion into hypoxic areas of tumor mass may be required to enhance its efficacy. With regard to higher incidences of muscle cramps as ADR, it appears to be reversible and of minor significance at optimal therapeutic doses. Limitations of our study include inclusion of different types of cancer patients and lack of sufficient number of studies. Though in a meta-analysis of survival data, individual patient data is preferable we tried to nullify this drawback by extracting the survival rate values at different time intervals. The accuracy of these extracted data cannot be authenticated and directly reflected to actual values. Presence of publication bias and other indicators of bias in the included studies add to the major drawback to the generalization of the study results.

\section{Funding: No funding sources}

Conflict of interest: None declared

Ethical approval: The study was approved by the Institutional Ethics Committee

\section{REFERENCES}

1. Torre LA, Bray F, Siegel RL, Ferlay J, Lortet-Tieulent J, Jemal A. Global Cancer Statistics, 2012. CA Cancer J Clin. 2015;65:87-108.

2. Murthy NS, Chaudhry K, Rath GK. Burden of cancer and projections for 2016, Indian scenario: gaps in the availability of radiotherapy treatment facilities. Asian Pac J Cancer Prev. 2008;9:671-7.

3. Brown JM. Tumor microenvironment and the response to anticancer therapy. Cancer Biol Ther. 2002;1:453-8.

4. Phillips RM. Targeting the hypoxic fraction of tumours using hypoxia-activated prodrugs. Cancer Chemother Pharmacol. 2016;77:441-57.

5. Marcu L, Olver I. Tirapazamine: From Bench to Clinical Trials. Current Clinical Pharmacol. 2006;1: 71-9.

6. Le QT, Taira A, Budenz S, Jo Dorie M, Goffinet DR, Fee WE, et al. Mature results from a randomized Phase II trial of cisplatin plus 5-fluorouracil and radiotherapy with or without tirapazamine in patients with resectable Stage IV head and neck squamous cell carcinomas. Cancer. 2006;106:1940-9.

7. Rischin D, Peters L, Fisher R, Macann A, Denham J, Poulsen M, et al. Tirapazamine, Cisplatin, and 
Radiation versus Fluorouracil, Cisplatin, and Radiation in patients with locally advanced head and neck cancer: a randomized phase II trial of the TransTasman Radiation Oncology Group (TROG 98.02). J Clin Oncol. 2005;23:79-87.

8. Rischin D, Peters LJ, O'Sullivan B, Giralt J, Fisher R, Yuen K, et al. Tirapazamine, cisplatin, and radiation versus cisplatin and radiation for advanced squamous cell carcinoma of the head and neck (TROG 02.02, HeadSTART): a phase III trial of the Trans-Tasman Radiation Oncology Group. J Clin Oncol. 2010;28:2989-95.

9. Williamson SK, Crowley JJ, Lara PN Jr, McCoy J, Lau DH, Tucker RW, et al. Phase III trial of paclitaxel plus carboplatin with or without tirapazamine in advanced non-small-cell lung cancer: Southwest Oncology Group Trial S0003. J Clin Oncol. 2005;23:9097-104.

10. von Pawel J, von Roemeling R, Gatzemeier U, Boyer $\mathrm{M}$, Elisson LO, Clark P, et al. Tirapazamine plus cisplatin versus cisplatin in advanced non-small-cell lung cancer: A report of the international catapult I study group. cisplatin and tirapazamine in subjects with advanced previously untreated non-small-cell lung tumors. J Clin Oncol. 2000;18:1351-9.

11. DiSilvestro PA, Ali S, Craighead PS, Lucci JA, Lee YC, Cohn DE, et al. Phase III randomized trial of weekly cisplatin and irradiation versus cisplatin and tirapazamine and irradiation in stages IB2, IIA, IIB, IIIB, and IVA cervical carcinoma limited to the pelvis: a gynecologic oncology group study. J Clin Oncol. 2014;32:458-64.

12. Tierney JF, Stewart LA, Ghersi D, Burdett S, Sydes MR. Practical methods for incorporating summary time-to-event data into meta-analysis. Trials. 2007;8:1-16.

13. Nancy GB, Robert AP. Meta-analysis: neither quick nor easy. BMJ Med Res Methodol. 2002;2:10.

14. Julian PTH, Altman DG, Gøtzsche PC, Jüni P, Moher $\mathrm{D}$, Oxman AD, et al. The Cochrane Collaboration's tool for assessing risk of bias in randomised trials. BMJ Med Res Methodol. 2011;343:d5928.

15. Brown JM, Giaccia AJ. The unique physiology of solid tumors: opportunities (and problems) for cancer therapy. Cancer Res. 1998;58:1408-16.

16. Huxham LA, Kyle AH, Baker JH, McNicol KL, Minchinton AI. Exploring vascular dysfunction caused by tirapazamine. Microvasc Res. 2008;75:24755.

17. Bhattacharya A, Tóth K, Durrani FA, Cao S, Slocum HK, Chintala S, et al. Hypoxia-specific drug tirapazamine does not abrogate hypoxic tumor cells in combination therapy with irinotecan and methylselenocysteine in well-differentiated human head and neck squamous cell carcinoma a253 xenografts. Neoplasia. 2008;10:857-65.

18. Kazmi N, Hossain MA, Phillips RM. A hybrid cellular automaton model of solid tumor growth and bioreductive drug transport. IEEE/ACM Trans Comput Biol Bioinform. 2012;9:1595-606.
19. Kazmi N, Hossain MA, Phillips RM, Al-Mamun MA, Bass R. Avascular tumour growth dynamics and the constraints of protein binding for drug transportation. J Theor Biol. 2012;313:142-52.

20. Masunaga S, Ono K, Suzuki M, Kinashi Y, Takagaki $\mathrm{M}$, Kasai S, et al. Changes in the sensitivity of intratumor cells during fractionated tirapazamine administration. Jpn J Cancer Res. 2000;91:731-6.

21. Masunaga S, Ono K, Hori H, Akaboshi M, Kawai K, Suzuki M, et al. Enhancement of cisplatin sensitivity of quiescent cells in solid tumors by combined treatment with tirapazamine and low-temperature hyperthermia. Radiat Med. 1998;16:441-8.

22. Yapp DT, Lloyd DK, Zhu J, Lehnert S. Radiosensitization of a mouse tumor model by sustained intra-tumoral release of etanidazole and tirapazamine using a biodegradable polymer implant device. Radiother Oncol. 1999;53:77-84.

23. Denny WA. Prospects for hypoxia-activated anticancer drugs. Curr Med Chem Anticancer Agents. 2004;4:395-9.

24. Evans JW, Yudoh K, Delahoussaye YM, Brown JM. Tirapazamine is metabolized to its DNA-damaging radical by intranuclear enzymes. Cancer Res. 1998;58:2098-101.

25. Biedermann KA, Wang J, Graham RP, Brown JM. SR 4233 cytotoxicity and metabolism in DNA repaircompetent and repair-deficient cell cultures. $\mathrm{Br} \mathrm{J}$ Cancer. 1991;63:358-62.

26. Skov KA, Adomat H, Farrell NP, Matthews JB. Assessment of toxicity of bis-platinum complexes in hypoxic and aerobic cells. Anticancer Drug Des. 1998;13:207-20.

27. Goldberg Z, Evans J, Birrell G, Brown JM. An investigation of the molecular basis for the synergistic interaction of tirapazamine and cisplatin. Int J Radiat Oncol Biol Phys. 2001;49:175-82.

28. Giaccia AJ, Biedermann KA, Tosto LM, Minchinton AI, Kovacs MS, Brown JM. Characterization of a $\mathrm{CHO}$ cell line resistant to killing by the hypoxic cell cytotoxin SR 4233. Int J Radiat Oncol Biol Phys. 1992;22:681-4.

29. Gilbert MS, Rupnow BA, Ramirez DA, Trisler KD, Knox SJ.Over-expression of Bcl-2 protects against apoptosis induced by the bioreductive cytotoxic drug SR4233 (Tirapazamine). Cell Death Differ. 1996;3:215-22.

30. Fitzpatrick B, Mehibel M, Cowen RL, Stratford IJ. iNOS as a therapeutic target for treatment of human tumors. Nitric Oxide. 2008;19:217-24.

31. Yang B, Reynolds CP. Tirapazamine cytotoxicity for neuroblastoma is p53 dependent. Clin Cancer Res. 2005;11:2774-80.

32. Vordermark D, Brown JM. Endogenous markers of tumor hypoxia predictors of clinical radiation resistance?. Strahlenther Onkol. 2003;179:801-11

33. Skarsgard LD, Skwarchuk MW, Vinczan A, Chaplin DJ. The effect of $\mathrm{pH}$ on the aerobic and hypoxic cytotoxicity of SR4233 in HT-29 cells. Br J Cancer. 1993;68:681-3. 
34. Wouters BG, Delahoussaye YM, Evans JW, Birrell $\mathrm{GW}$, Dorie MJ, Wang J, et al. Mitochondrial dysfunction after aerobic exposure to the hypoxic cytotoxin tirapazamine. Cancer Res. 2001;61:145-52.

35. Barnard RJ, Youngren JF. Regulation of glucose transport in skeletal muscle. FASEB J. 1992;6:3238-

Cite this article as: Hiremath SB, Devendrappa SL. Safety and efficacy of tirapazamine as anti-cancer drug: a meta-analysis of randomized controlled trials. 44. 